\title{
Ob sedemdesetletnici Franceta Novaka
}

\author{
Majda Merše
}

IZVLEČEK: Dr. France Novak praznuje dvojni jubilej: sedemdeseti rojstni dan in štirideseto obletnico prihoda na Inštitut za slovenski jezik Frana Ramovša. Ob tej priliki je bila pregledana njegova življenjska pot in opozorjeno na njegove številne raziskovalne in strokovne dosežke. Začrtan je bil obseg njegovega slovarskega dela ter leksikoloških (zlasti pomenoslovnih), funkcijskozvrstnih in jezikovnozgodovinskih raziskav.

\section{ON France NovaK's 70 $70^{\text {th }}$ BIRTHDaY}

ABSTRACT: For France Novak, Ph.D., this is a celebration of two jubilees: his $70^{\mathrm{th}}$ birthday and the $40^{\mathrm{th}}$ anniversary since he first came to work at the Fran Ramovs Institute of the Slovene language. The article draws attention to his numerous research and professional achievements, as well as to his lexicographic work and research in lexicology (especially in semantics), register and style, and in historic linguistics.

Prvega novembra, na dan, ki je že v Trubarjevem kole(n)darju iz leta 1557 označen kot praznik vseh svetnikov in ki mu še danes običajno pravimo »vsi svêti«, je sedemdeseti rojstni dan praznoval France Novak. Mesec dni pred tem je tiho minila tudi štirideseta obletnica njegovega prihoda na Inštitut za slovenski jezik: minilo je štirideset zelo delavnih in raziskovalno plodnih let, ki jih je preživel v dveh sekcijah inštituta. Prvi november 2004 je v življenju jubilanta opaznejši mejnik tudi zato, ker se je prav s tem datumom upokojil.

France Novak se je rodil kmečkim staršem na Gorenjem Vrhu pri Dobrniču. Družinsko in vaško okolje mu je privzgojilo stroge delovne navade ter občutek za tradicionalne življenjske vrednote, med katerimi se povsem samoumevno zelo visoko uvrščata tudi poštenost in resnicoljubnost. Za dediščino je dobil tudi gibko, pronicljivo misel ter priljuden, veder značaj, kar je pustilo sledove v sleherni delovni skupini, katere član je bil.

Gimnazijo je obiskoval v Novem mestu. Po maturi leta 1955 se je vpisal na slavistični oddelek ljubljanske Filozofske fakultete. Diplomiral je leta 1960 iz slovenskega in srbohrvaškega jezika s književnostmi. Po odsluženi vojaščini je prav 
tako na Filozofski fakulteti v Ljubljani vpisal tretjestopenjski študij, smer slovanska etimologija in onomastika. Za magistrsko nalogo z naslovom Slovensko jamsko imenoslovje je leta 1965 dobil Prešernovo nagrado za študente. Magistrskega izpita in zagovora naloge ni opravljal. 26. maja 1995 je uspešno zagovarjal doktorsko disertacijo $\mathrm{z}$ naslovom Samostalniška večpomenskost v jeziku slovenskih protestantskih piscev 16. stoletja.

Leta 1964 se je zaposlil na Inštitutu za slovenski jezik pri Slovenski akademiji znanosti in umetnosti. Sprva je delal v Leksikološki sekciji inštituta. Bil je soavtor in sourednik prvih dveh knjig Slovarja slovenskega knjižnega jezika (dalje SSKJ). Redaktorsko delo je prekinil $v$ času dvakratnega študijskega bivanja $v$ tujini. Leta 1965 je bil pet mesecev v Pragi, kjer se je jezikovno in strokovno izpopolnjeval na Filozofski fakulteti Karlove univerze ter na akademijskem Inštitutu za češki jezik. Leta 1971 je mesec dni izpopolnjeval znanje ruščine v Moskvi. Oktobra leta 1976 je (sredi priprav za tretjo knjigo SSKJ) prestopil v komaj ustanovljeno zgodovinsko sekcijo inštituta, $v$ kateri naj bi nastajali zgodovinski slovarji, kot prvi med njimi pa Slovar jezika slovenskih protestantskih piscev 16. stoletja. France Novak je bil vse od ustanovitve leta 1973 tudi član komisije strokovnjakov za leksikološka vprašanja (imenovane Komisija za historične slovarje slovenskega jezika), ki je pod predsedstvom akademika Franceta Bezlaja sprva vodila delo sekcije, od 24. aprila leta 1987 dalje pa je bil tudi uradno vodja sekcije.

France Novak je z delom na Inštitutu za slovenski jezik pričel kot asistent. Leta 1972 je bil izvoljen v naziv višji strokovni sodelavec, leta 1983 pa v naziv strokovni svetnik. Leta 1994 je po prevedbi, opravljeni na osnovi kolektivne pogodbe, dobil naziv strokovni sodelavec s specializacijo, leta 2001 pa naziv samostojni strokovni sodelavec specialist $\mathrm{v}$ humanistiki. Za ustrezen znanstveno-raziskovalni naziv, do katerega bi na osnovi znanstvenih in strokovnih dosežkov nedvomno bil upravičen, ni zaprosil, ker si je zanj postavil zelo stroga lastna merila. Na to, da so mu njihovo izpolnitev onemogočala objektivna dejstva, se ni oziral.

Že polni dve desetletji poučuje slovenski knjižni jezik in poslovno komuniciranje na Višji oz. Visoki upravni šoli v Ljubljani, ki je $v$ zadnjem času prerasla v Fakulteto za upravo, od leta 1998 pa kot docent za slovenski jezik predava tudi na Pedagoški fakulteti v Mariboru. Prav vestno pedagoško delo mu je v zadnjem desetletju zaseglo zelo veliko moči in prostega časa, saj so se obveznosti zaradi naraščajočega števila študentov močno povečale, pa tudi zato, ker je v skladu s svojimi trdnimi pedagoškimi načeli skušal dosegati zadovoljivo kakovost znanja pri vseh študentih, ne glede na njihovo število.

V letih 1992-1995 je bil predsednik Slavističnega društva Slovenije. Od leta 1992 je član Delovne skupine za jezikovno načrtovanje in jezikovno politiko pri Odboru za kulturo, šolstvo in šport Državnega zbora Republike Slovenije. V letih 1996-1999 je bil član Upravnega odbora ZRC SAZU, od leta 1997 pa kot član uredniškega odbora vsebinsko in programsko sooblikuje tudi Jezikoslovne zapiske, glasilo Inštituta za slovenski jezik Frana Ramovša.

Prvi tiskani prispevek, ki ga »zaznava« jubilantova bibliografija, je članek, napisan ob petdesetletnici smrti pesnika Kranjčevića (Tribuna 1958). Prispevku kronološko sledi dolga vrsta ocen literarnih del, ki so v letih 1960-1964 izšle v 
Naši sodobnosti oz. Sodobnosti in ki razkrivajo avtorjevo živo zanimanje za domačo in tujo sodobno literaturo, še posebej pa za poezijo. Hkrati je v Slavistični reviji, Jeziku in slovstvu in Naših razgledih, nekaj let kasneje pa tudi v Gospodarskem vestniku, izšlo več jezikoslovnih prispevkov, ki že nakazujejo kasnejšo tematsko razsežnost, raznolikost, medsebojno prepletenost in temeljitost Novakovih jezikoslovnih raziskav.

Pregled tematike, obravnavane v jezikoslovnih delih Franceta Novaka, kaže na pripadnost štirim osnovnim tematskim področjem, ki se praviloma stikajo in prepletajo, le redko pa so opazneje razmejena. Oblikujejo jih: (1) slovaropisne teme; nanje se logično navezujejo (2) besedoslovne raziskave: zlasti s pomenoslovnim jedrom, ki bi ga bilo mogoče zaradi raziskovalne osrednjosti in razsežnosti obravnavati tudi kot samostojno tematsko področje, ter s podpodročji, ki jih predstavljajo imenoslovje ter strokovni jezik in terminologija, ki hkrati ustvarjata gladek prehod k (3) obravnavam funkcijske zvrstnosti jezika. Kot četrto tematsko področje je mogoče obravnavati jezikovnozgodovinske teme, čeprav je tako sodobni kot zgodovinski pristop mogoče zaznati pri raziskavah $\mathrm{z}$ vseh tematskih področij.

Jubilantovo zanimanje za ožje slovaropisne teme se je razkrilo že v najzgodnejših objavah (npr. v ocenah poskusnega snopiča Etimološkega slovarja slovenskega jezika (Naši razgledi 1963), poskusnega snopiča Slovarja slovenskega knjižnega jezika (Sodobnost 1964) in drugje). Delo pri SSKJ, vključenost v pripravljalna dela za Slovar jezika slovenskih protestantskih piscev 16. stoletja in sodelovanje pri drugih nalogah Sekcije za zgodovino slovenskega jezika pa ga je tudi kasneje nenehno usmerjalo $\mathrm{k}$ tovrstnim raziskavam. Izid prvega dela SSKJ ga je npr. spodbudil k razvojnemu prikazu slovenske leksikografije (O razvoju slovenske leksikografije, VI. seminar slovenskega jezika, literature in kulture, Ljubljana 1970), slovarsko in raziskovalno ukvarjanje s knjižnim jezikom 16. stoletja pa $\mathrm{k}$ prikazu dosežkov slovenske reformacije na leksikografskem in leksikološkem področju (Leksikografija in leksikologija $v$ slovenski reformaciji, Leksikografija i leksikologija, Akademija nauka i umjetnosti Bosne i Hercegovine, Posebna izdanja LXXXV, Sarajevo 1988). V enem izmed strokovnih sestavkov je (strokovno) javnost seznanil s pripravljalnimi deli za slovenski zgodovinski slovar, zlasti pa z že doseženemi rezultati (Jezik in slovstvo 27, 1981/82), v posebni razpravi pa $z$ vprašanjem gradiva za zgodovinski slovar ter s konkretno problematiko popolnega izpisa, s katerim je bilo zbrano gradivo za Slovar jezika slovenskih protestantskih piscev 16. stoletja (Rječnik i društvo, Zagreb 1993).

Jubilantove slovaropisne teme zadnjega desetletja kažejo na zanimanje za starejše, večinoma dvojezične slovarje, čeprav je bil nastanek sestavkov običajno spodbujen z obletnicami. Novomeška Rast (1994) npr. prinaša podrobnejšo predstavitev Pleteršnikovega slovarja, Murkov zbornik (Zora 9, Maribor 1999) pa prikaz zgradbe tipičnega slovarskega sestavka v Murkovem slovarju. Na Novakovo temeljito teoretično in praktično poznavanje slovaropisja kažejo tudi primerjalne osvetlitve obravnavane problematike, v katere so vpleteni številni drugi (starejši ali sočasni) slovarji in slovarniki (npr. Pohlin, Gutsmann, Jarnik, Janežič, Cigale, predvsem pa SSKJ), kar hkrati povečuje tudi vedenje o njih.

Med slovaropisne teme se uvršča tudi zamisel o zapisovanju besednega 
zaklada govorjenega jezika v posameznih krajih. Oživela je kot pobuda Slavističnega društva Slovenije, v veliki meri pa jo je izoblikoval prav jubilant sam. Predstavil jo je dvakrat: v Traditiones 23, Ljubljana 1994 (Zapisovanje besednega zaklada govorjenega jezika v posameznih krajih) in v Zborniku Slavističnega društva Slovenije 5, Ljubljana 1997 (Predstavitev zamisli o zapisovanju besednega zaklada govorjenega jezika v posameznih krajih). V sestavkih je avtor povzel lastno zamisel ter mnenja številnih raziskovalcev jezika in njegovih ljubiteljev. Oboje naj bi za začetek spodbudilo razpravo o načrtu in privedlo do pričakovane dopolnitve zamisli, čemur naj bi sledila njena uresničitev.

Vztrajno in v tesni povezavi s slovarskim delom se je France Novak loteval besedoslovnih tem. $\mathrm{Z}$ njimi zaobsega tipologijo besedja pri posameznih piscih iz naše literarne preteklosti, bodisi znotraj posameznega dela (npr. v Trubarjevem delu CATEHISMVS SDVEIMA ISLAGAMA, 1575), kar omogoča natančnejšo analizo in predstavitev, ali znotraj celotnega opusa (npr. Kersnikovega). Trubarjevo besedje je npr. analizirano glede na tematiko, izvor, stilnost in pomenskost (Besedje Trubarjevega dela Catehismus z dveima izlagama iz 1. 1575, Vatroslav Oblak, Obdobja 17, Ljubljana 1998), tipologija Kersnikovega besedja pa je določena ob upoštevanju vsebinsko-področnih in slogovnih skupin (Janko Kersnik in njegov čas, Zbornik Slavističnega društva Slovenije 8, Ljubljana 1998). Med dela, ki jih jubilant sam uvršča med pomembnejše raziskovalne dosežke, spada zgodnja razprava Arhaizacija v Visoški kroniki (Jezik in slovstvo 20, 1974/75). V njej so obravnavani tipi starinskih izraznih sredstev, ki jih je Tavčar namerno uporabil v Visoški kroniki.

Jedro celotnega Novakovega raziskovalnega dela predstavljajo pomenoslovne teme, zlasti obravnava (samostalniške) večpomenskosti. Namenjene so jim številne razprave, ki analizirajo pomenske pojave bodisi na osnovi sodobnega ali v preteklih obdobjih uporabljanega besednega zaklada (npr. Vloga skladnje pri določanju in dokazovanju pomenskih lastnosti besedja, XI. seminar slovenskega jezika, literature in kulture, Ljubljana 1975; Vprašanja pomenske analize leksike starejših obdobij, Leksikografija i leksikologija, Beograd - Novi Sad 1982; Pomenske značilnosti besednega zaklada slovenskih protestantskih piscev, XX. seminar slovenskega jezika, literature in kulture, Ljubljana 1984; Vprašanja pomenske skupine $v$ besedišču pri slovenskih protestantih, Družbena in kulturna podoba slovenske reformacije, Ljubljana 1986).

Tudi v zadnjih petnajstih letih je pomenoslovnim temam vsaj nekaj prostora odmerjenega $\mathrm{v}$ večini Novakovih problemsko specializiranih raziskav, zlasti pa raziskav jezika slovenskih protestantskih piscev 16. stoletja (npr. v razpravah Pomen raziskovanja besedja knjižnega jezika 16. stoletja za jezikoslovje, Samostalniška večpomenskost $v$ knjižni slovenščini 16. stoletja glede na prevodne zglede in drugod). Samostalniška večpomenskost je bila tudi tema njegove disertacije. Prav pred kratkim je izšla obsežna monografija z (enakim) naslovom Samostalniška večpomenskost $v$ jeziku slovenskih protestantskih piscev 16. stoletja, ki strnjuje, nadgrajuje ter problemsko in $\mathrm{z}$ novimi vidiki dopolnjuje avtorjevo dosedanje raziskovanje (samostalniške) večpomenskosti, ki jo obravnava kot lastnost knjižnojezikovnega sistema. V monografiji so predstavljeni vsi pomenskorazvojni modeli, ki so bili v knjižnem jeziku 16. stoletja aktivni pri tvorbi drugotnih pomenov (metaforizacija, 
metonimizacija, terminologizacija, natančnejše določanje pomenov, približevanje, preobrnitev, poosebitev, besedna igra, frazeologizacija, simbolizacija, primerjava, nastanek priliških pomenov in nastanek pomenov, vezanih na liturgična besedila). Eden izmed osnovnih ciljev monografije je bil tudi odkritje vseh tipov pomenskih prehodov ter pomenskih zakonov, po katerih le-ti nastajajo. Odkrivanje večpomenskostnih pojavov je potekalo znotraj celotnega sistema besednega zaklada, na osnovi analize obsežnega gradiva, dobljenega s popolnim izpisom del slovenskih protestantskih piscev 16. stoletja. Zaradi vsega naštetega bo delo dober študijski in delovni priročnik slovaropiscev, zlasti zgodovinskih. Poleg temeljnih ugotovitev, ki se nanašajo na samostalniško večpomenskost, delo prinaša tudi več priložnostnih ugotovitev, ki izpopolnjujejo splošno vedenje o slovenskem knjižnem jeziku 16. stoletja. Slednjega bogatijo tudi številni drugi raziskovalni prispevki Franceta Novaka.

France Novak večpomenskost obravnava tudi kot enega izmed poimenovalnih načinov v slovenščini. Tudi tem namenja veliko pozornosti, tako v okviru jezikovnozgodovinskih raziskav kot pri raziskavah sočasnih funkcijskih zvrsti (zlasti poslovnega in uradovalnega jezika) ter sočasnega strokovnega jezika. Vztrajno »vračanje« k problematiki večpomenskosti, pa tudi raziskovanje poimenovalnih načinov in zanimanje za terminološko problematiko, so opazne povezovalne niti Novakovih jezikoslovnih raziskav, ki hkrati svojsko homogenizirajo njegovo delo.

Več razprav se ukvarja s terminološko problematiko. Najtemeljiteje je (v eni izmed njih) predstavljena slovenska jamska terminologija (Onomastica Jugoslavica 10, Zagreb 1982). Jezikovna analiza izbranih del iz preteklosti (npr. Koliherjevega rokopisa o rastlinskih zdravilih iz leta 1750 , Pohlinovih Bukuvz fa rajtengo iz leta 1781, Dajnkove knjige Čelarstvo iz leta 1811, Slovenskega glasnika (v obdobju 1858-1868) ter Thumove Alpinske terminologije, ki je nastajala $v$ tridesetih letih 20. stoletja) je izpostavila tudi $\mathrm{v}$ njih uporabljeno matematično (Iz zgodovine slovenskega znanstvenega jezika: Pohlinova računica, Slovenski jezik v znanosti 1, Zbornik prispevkov, Ljubljana 1986), čebelarsko (Dajnkovo čebelarsko izrazje, Dajnkov zbornik, Zora 3, Maribor 1998), alpinsko (Terminološka prizadevanja s posebnim ozirom na Henrika Tumo, Socialni realizem v slovenskem jeziku, književnosti in kulturi, Obdobja 7, Ljubljana 1987), vzorčno pa tudi druge terminologije, npr. botanično in medicinsko (Jezik Koliherjevega rokopisa, Slovenska medicinska beseda, Medicinski razgledi, Ljubljana 1984) ter pravno. Z razpravami Terminologija $v$ Slovenskem glasniku (Obdobje realizma v slovenskem jeziku, književnosti in kulturi, Obdobja 3, Ljubljana 1982), Terminološka prizadevanja s posebnim ozirom na Henrika Tumo in Leksikalne spremembe $v$ slovenskem poslovnem in uradovalnem jeziku (Jezik in čas, Ljubljana 1996) je avtorju hkrati uspelo zarisati skorajda strnjen lok razvoja terminologije za obdobje, ki se pričenja sredi 19. stoletja, končuje pa sredi devetdesetih let 20. stoletja. Razprave razvojno povzemajo temeljno terminološko problematiko, prikazujejo pa tudi tvorbene tipe in izvorno različnost terminov.

$\mathrm{Z}$ imenoslovnimi temami se je France Novak intenzivneje ukvarjal zlasti v zgodnejšem raziskovalnem obdobju. V magistrski nalogi, v sestavkih, objavljenih v Gospodarskem vestniku (npr. Imena gospodarskih in drugih organizacij, raznih 
ustanov in združenj), v oceni Rospondove monografije Słowiańskie nazwy miejscowe z sufiksem -bsk- (Onomastica Jugoslavica 2, Ljubljana 1970), v razpravi Imena $v$ starejših slovenskih slovarjih (Zbornik Šeste jugoslovenske onomastičke konferencije, Beograd 1987), ki upošteva slovarje, nastale od 16. do konca 19. stoletja, in drugje, je obravnaval tvorbeno, oblikovno, razvojno in drugo problematiko osebnih, zemljepisnih in stvarnih lastnih imen.

Tretje tematsko jedro, ki Franceta Novaka že desetletja priteguje, je problematika funkcijske zvrstnosti jezika, zlasti poslovnih in uradovalnih besedil. Leta 1980 je izšla monografija Poslovni in uradovalni jezik, s katero je avtor povzel in zaokrožil dotedanje raziskovanje te jezikovne zvrsti, trajajoče skoraj poldrugo desetletje. Več krajših sestavkov, ki so v letih 1967-1969 izšli v Gospodarskem vestniku, je v monografijo vključil kot posebna poglavja (npr. O splošni rabi, $O$ prožni stabilnosti knjižnega jezika, Kako rušimo jezikovno stabilnost itd.).

Na Fakulteti za upravo je poleti 2004 izšla že tretja, precej razširjena in izpopolnjena izdaja učbenika z naslovom Študijsko gradivo za jezikoslovni del predmeta Poslovno in uradovalno komuniciranje (prva izdaja leta 2001, druga pa leta 2002). Učbenik je izvirno delo, vsebinsko smiselno prirejeno poklicnim potrebam delavcev z visoko upravno izobrazbo. Vsebuje jezikoslovno-teoretični (prvi) in besediloslovni (drugi) del. V prvem delu (z naslovom Slovnične in stilistične osnove jezika poslovnega in uradovalnega komuniciranja) je snov obravnavana v klasičnem slovničnem zaporedju, ki odslikuje logično razvrstitev ravnin jezikovne zgradbe. V vsakem izmed poglavij pa je poleg temeljnih jezikoslovnih dejstev obravnavana tudi problematika, značilna za področje poslovanja in uradovanja. Posebej aktualni problematiki, ki jo je avtor poznavalsko izbral, je namenjenega več prostora: npr. trpniku kot obliki, ki je pogosta $\mathrm{v}$ poslovnih in uradovalnih besedilih. $\mathrm{V}$ drugem delu so za uvodnimi besediloslovnimi poglavji po preizkušenem metodološkem modelu obravnavani najpogosteje uporabljani besedilni vzorci (npr. akt, dopis, navodilo, odločba, pogodba, prošnja, zakon itd.). Primerjava izdaj kaže, da avtor priročnik načrtno vsebinsko dopolnjuje in metodološko izboljšuje, oboje na osnovi dolgoletnih pedagoških izkušenj in večdesetletnega aktivnega teoretičnega in praktičnega jezikoslovnega delovanja.

Posameznim vprašanjem s tega tematskega področja je jubilant posvetil tudi posebne raziskave. Posebno pozornost je npr. namenil vprašanjem stilistike $v$ poslovnih in uradovalnih besedilih (prispevek je predstavil na okrogli mizi $\mathrm{z}$ naslovom Poslovna in uradovalna slovenščina $v$ zgodovini in danes, ki jo je sam tudi pripravil in vodil, potekala pa je v okviru Slovenskega slavističnega kongresa leta 1999 v Celju (Slovensko jezikoslovje danes in jutri, Zbornik Slavističnega društva Slovenije 10, Ljubljana 2000). Preveril je tudi vlogo večpomenskosti pri strokovnem izrazju (Večpomenskost in strokovno izrazje, Slovensko naravoslovnotehnično izrazje, Ljubljana 1998). Ugotovil je, da ima slednja pomemben delež pri nastanku strokovnega jezika, saj je terminološki pomen pogosto eden izmed pomenov ali pomenskih odtenkov večpomenskih besed. Hkrati je opozoril, da je njena vloga v znanstvenem jeziku manjša kot pri drugih funkcijskih zvrsteh.

Pod dokaj splošnim naslovom Slovenski jezik, ekonomija in kultura (Sožitje ekonomije in kulture kot priložnost za uspešen razvoj Slovenije, 6. seminar o 
poslovnem napovedovanju in učinkovitem odločanju v zaostrenih gospodarskih pogojih, Novo mesto 1994) se »skriva« razmišljanje o jeziku v ekonomiji kot o svojevrstnem jezikoslovnem vprašanju ter o dveh nadaljnjih pojavih: o znanstvenem jeziku ekonomije in o poslovnem jeziku gospodarskega področja kot o njegovi »praktični različici«.

$\mathrm{K}$ raziskovalnemu ugotavljanju leksikalnih sprememb, ki so se v slovenskem poslovnem in uradovalnem jeziku dogodile $\mathrm{v}$ obdobju po drugi svetovni vojni (Leksikalne spremembe $v$ slovenskem poslovnem in uradovalnem jeziku, Jezik in čas, Ljubljana 1996), je Novaka usmerilo tudi zanimanje za zgodovino slovenskega jezika. Ugotavljal jih je na osnovi primerjave štirih slovenskih in (ene) jugoslovanske ustave ter variant zakona o delovnih razmerjih. Prispevek potrjuje ugotovitev, da so leksikalne spremembe $\mathrm{v}$ poslovnem in uradovalnem jeziku odvisne od spremembe zakonodaje. Poleg besednih so navedene tudi spremembe $z$ drugih jezikovnih ravnin.

France Novak je bil v zadnjem desetletju tudi mentor številnih diplomskih nalog $\mathrm{s}$ tematiko iz poslovnega in uradovalnega komuniciranja.

Med rezultate skoraj tridesetletnega ukvarjanja $\mathrm{z}$ jezikom slovenskih protestantskih piscev 16. stoletja oz. sodelovanja pri pripravljalnih delih za slovar jezika slovenskih protestantskih piscev 16. stoletja spada vrsta sestavkov, ki z različnih vidikov izpostavljajo bodisi raziskovanje knjižnega jezika 16. stoletja kot sistemske celote in $\mathrm{z}$ upoštevanjem vseh ravnin jezikovne zgradbe (glasoslovne, naglasne, oblikoslovne, besedotvorne, skladenjske, besedne, stilistične in pravopisne) ali pa le posamezne izmed njih (npr. skladenjske: Stavčna tipologija v Dalmatinovi Gmajn predguvori čez vso sveto Biblio, Jezik in slovstvo 29, 1983/84), najpogosteje besedne (npr. že omenjena razprava Besedje Trubarjevega dela Catehismus z dveima izlagama iz $l$. 1575 ter razprava Razvojne tendence $v$ besedišču slovenskih protestantskih piscev, 16. stoletje $\mathrm{v}$ slovenskem jeziku, književnosti in kulturi, Obdobja 6, Ljubljana 1986). Posebej ga zanima tudi razmerje med narečno in knjižno rabo, ki ga je prav tako treba ugotavljati na vsaki ravnini posebej, ter jezikovna vplivnost prevodnih predlog.

Dva prispevka, ki bi ju bilo mogoče prištevati tudi k pomenoslovnim razpravam, sta zaradi obravnave ključne prevodne problematike vredna posebne omembe: Kako so protestantski pisci 16. stoletja poimenovali nove pojme (450letnica slovenske knjige in slovenski protestantizem, Ljubljana 2001) in Samostalniška večpomenskost $v$ knjižni slovenščini 16. stoletja glede na prevodne zglede (Slavistična revija 46, 1999). V prvem je predstavljeno protestantsko videnje ter praktično reševanje problematike ubesedovanja nove vsebine, zlasti pa zadrege, kako priti do izrazov za pojme, ki so bili v jezikih, iz katerih so prevajali, poimenovani, v slovenščini pa ne. Avtor po pogostnostnem zaporedju navaja naslednje postopke: stvaritev nove tvorjenke, prevzem bolj ali manj prilagojenega tujega izraza, opisna razlaga, večpomenskost, večbesedno poimenovanje (najpogosteje sestavljeno iz nadpomenke in uvrščevalnega izraza), uporaba nenevtralnega izraza iz živega govora, približni izraz, kalkiranje. V drugem sestavku pa so predstavljeni glavni tipi motivacij za samostalniško večpomenskost v drugi polovici 16. stoletja. Izoblikovana je naslednja tipologija: drugotni pomeni (zlasti 


$$
\text { Bnil }
$$
slovar pripravila za natis (Ljubljana 1997).

Nekaj bibliografskih enot kaže, da z naštetimi tematskimi področji jubilantova raziskovalna širina še ni v celoti zaobsežena. Omeniti je treba vsaj še dva vsebinsko različna prispevka. Na področje narečjeslovja je npr. France Novak posegel s fonološkim opisom govora Bučke, ki ga je skupaj z Jakobom Riglerjem izdelal po vzorcu za OLA (Fonološki opisi srpskohrvatskih/hrvatskosrpskih, slovenačkih i makedonskih govora obuhvaćenih opšteslovenskim lingvističkim atlasom, Sarajevo 1981). V praznovanje šestdesetletnice delovanja Slavističnega društva Slovenije pa se je kot takratni predsednik vključil tudi z izčrpnim in preglednim, hkrati pa programskim in mestoma kritičnim prispevkom o nalogah in možnostih Slavističnega društva Slovenije (Zbornik Slavističnega društva 6, Ljubljana 1997).

Rezultati Novakovih raziskav so poleg odpiranja novih tematskih področij 
korigirajo ali dopolnjujejo že znano. Praviloma so dosežene na osnovi temeljitih analiz. Jubilant je pri delu običajno zavestno izbiral kolikor mogoče objektivne metode raziskovanja in opisovanja pojavov. Njegove prispevke odlikuje tudi nonazarjanje povedanega s skrbno izbranimi zgledi. Večina razprav in člankov

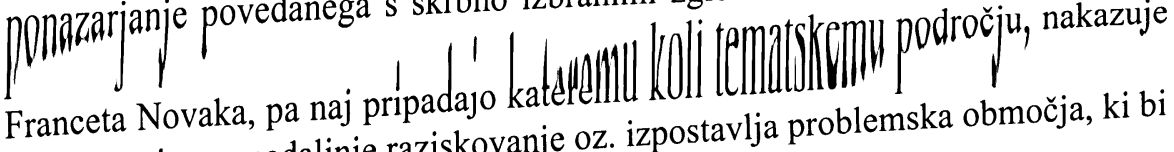
tudi smernice za nadaljnje raziskovanje oz. izpostav ja prob

bila potrebna natančnejših pretresov in novih osvetieve tudi na odprtost Franceta Številni večavtorski prispevki posredno kažejo tudi nazprav in člankov so npr. Novaka za strokovno sodelovanje. Mroksoly, Majda Merše, Franc Jakopin in drugi.

Naj $k$ celovitejšemu orisu jubilantove ramba naslednjih dejstev:

v minulih štiridesetih letih pripomore v letih 1967-1976 in 1982-1985 je jubilant

Od leta 1966 dalje, zlasti pa vedavanj za Radio Ljubljana, v letih 1980 in pripravil več ciklov jezikoslovnih predavizijsko oddajo Slovenščina v javni rabi. 1981 pa tudi trinajst prispevkov za in zvrsteh slovenskega jezika, o sestavih Tipkopisi predavanj o funkcijskih zu in glagolskih pomenov, o jeziku naših samostalniških, pridevniških, prislovniavcih z inštituta dolga leta iskano in cenjeno reformatorjev in drugem, so Za rubriko Predstavitve slovenističnih k $k$ času Novakovega predsednikovanja slavistov v Krškem leta 1994, torej prav v Casu orisa dveh del: Pavle Zdovc: SlovenSlavističnemu društvu Slovenije, je prisperom Koroškem (Maks Pleteršnik, Zbornik ska krajevna imena na avstrijskem Kona 1997) in Slovar jezika slovenskih Slavističnega društva Slovenije 5, L jubuni snopič (Zbornik Slavističnega društva protestantskih piscev 16. stoletja, P Jezikoslovnih zapiskih 6, Ljubljana 2000, pa je Slovenije 13, Ljubljana 20 Kucharja Právo a slovenčina v dejinách. K izboru ga je predstavil knjigo Rudola Kuchavinska tematika oz. njihov slovarski značaj. nagnila njihova jezikovnozgodovin bibliografije odkriva tudi prispevke, ki dokazujejo Pregled Novakove obsežne biblelovanji na okroglih mizah, v dnevnem tisku, zelo dejavno pripadnost stroki. S sodelovanja, se je udeleževal aktualnih razpravljanj pri raznovrstnih akcijah Slavističnega drine, pouku strokovnega jezika itd. Na okrogli o slovenskem jeziku, pouku slovenšč mizi z naslovom Slovensclavistov leta $1995 \mathrm{v}$ Ljubljani, je sodeloval z obsežnejšim, problemsko zaokroženim diskusijskim prispevkom $O$ slovenščini v strokovnih šolah, $\mathrm{v}$ katerem je opozoril na nujnost poučevanja strokovne slovenšcine vseh vrstah strokovnega šolstva ter razgrnil lastno zamisel, oprto na doblemske sklope, ki jih strokovnega šolstva ter razgrnil lastno zamisel, opro
izkušnje. Izpostavil je tri osrednje, medsebojno povezane problemske sklope, ki jih
oblikujejo: uporaba jezikovnega sistema na določenem področju, strokovno izrazje
. tega področja in besedila, ki se uporabljajo na tem plasilih je opozoril na več osrednjih S poročili v dnevnem tiskistiki (npr. na 12. mednarodni kongres slavistov, ki dogodkov v slavistiki in slovenistiki (npr zapiski 4, Ljubljana 1998). je bil leta 1998 v Krakovu, Jezikosl štirih desetletjih udeležil številnih strokovnih in S predavanji se je $v$ minnla sloveniji, na širšem območju nekdanje znanstvenih srečanj, ki so potekala $v$ Sloveniji, na siršem 

Milanovac itd.), pa tudi zunaj meja nekdanje in sedanje države (Krakov).

Jubilantovi znanstveni in strokovni prispevki so objavljeni $\mathrm{v}$ zbornikih prispevkov s simpozijev, zborovanj, znanstvenih konferenc in kongresov, veliko število pa tudi v strokovnih revijah in glasilih, kot so Slavistična revija, Jezik in slovstvo, Jezikoslovni zapiski, pa tudi Traditiones, Rast, Gospodarski vestnik itd.

Kot zavzet in odgovoren član Upravnega odbora Slavističnega društva Slovenije je leta 2002 prevzel izredno zahtevno uredništvo povzetkov za 13. mednarodni slavistični kongres (Ljubljana, 15.-21. avgust 2003), ki je poleg jezikoslovne terjalo tudi veliko praktične iznajdljivosti. Knjigi s skoraj osemsto povzetki, napisanimi v različnih jezikih in zelo različne tehnične kakovosti, sta kljub vsemu (tudi po zaslugi številnih Francetovih v noči podaljšanih delovnih dni) izšli pravočasno.

Tako kot pripadnosti stroki se je France Novak vseskozi ponosno zavedal tudi pripadnosti Inštitutu za slovenski jezik Frana Ramovša in jo odgovorno uresničeval tudi pri vseh delovnih zadolžitvah izven inštituta in na drugih delovnih področjih. Na pomen Slovarja slovenskega knjižnega jezika in drugih inštitutskih slovarskih dosežkov je opozarjal kot predsednik Slavističnega društva Slovenije in kot pedagog.

Njegovi sodelavci mu veliko dolgujemo: dolgoletni več, mlajši manj. Prav vsi pa smo bili deležni Francetovega nesebičnega razdajanja znanja in premišljenih, dobronamernih, nikoli zavajajočih nasvetov. Obojega smo bili deležni v tolikšni meri, da se nam je takó dajanje kot sprejemanje včasih zdelo skorajda samoumevno. Naj se mu za vse prejeto toplo zahvalimo vsaj ob tej priliki.

Pri skupinskih delih, ki so potekala v Sekciji za zgodovino slovenskega jezika, je bila zelo dragocena tudi njegova nenehna pripravljenost za konstruktiven strokovni dialog in za to, da kadar koli, brez obotavljanja, stopi na naporno, vijugasto, vzpenjajočo in spuščajočo se, neredko pa tudi zastajajočo ali celo napačno pot iskanja najboljše jezikoslovno-slovaropisne rešitve. Rezultat njegovega dolgoletnega slovarskega in raziskovalnega dela je tudi večkrat poudarjeno, pomirjujoče prepričanje, da pri reševanju težje, slovarsko aktualne jezikoslovne problematike neredko - ne glede na končni cilj - zadošča že dejstvo, da je »pot prava«.

Marsikateri širše zasnovani raziskovalni načrt Franceta Novaka je v zadnjem desetletju obtičal pri začetnih analizah ali pri osnovnih, prvostopenjsko povzetih rezultatih, s katerimi je seznanjal strokovno publiko na simpozijih, za kasnejšo dodelavo in za dodatne analize pa je zaradi obilice drugih, neodložljivih obveznosti zmanjkalo časa. Zaželimo mu, da bi mu ga za kaj nehote odloženega in za vse hote odloženo naklonila naslednja leta. Teh naj bo še dolga vrsta in naj mu ne zagrenijo nasmeha in ne skalijo vedrine. Naklonijo naj mu - tudi $\mathrm{v}$ dobro slovenskega jezikoslovja, zlasti zgodovinskega - trdnega zdravja in veliko zadovoljstva - ob raziskovalnem delu in ob vsem drugem, še zlasti pa ob Zali, Nejcu, Janu ...

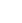

